\title{
Thyroid peroxidase antibodies in children with autoimmune thyroiditis
}

\author{
A Väkevä, S Kontiainen, A Miettinen, A Schlenzka, J Mäenpää
}

\begin{abstract}
Aims: To compare the prevalence of thyroid peroxidase antibodies in 25 children with autoimmune thyroid disorders and in 41 children and young adults with type 1 diabetes, and to test the prevalence of thyrotropin receptor antibodies.

Methods: Two commercially available radioimmunoassays for antibodies to thyroid peroxidase, a commercially available agglutination test of particles coated with thyroid microsomal antigens, and a radioimmunoassay for thyrotropin receptor antibodies were used. Patients and controls were studied.
\end{abstract}

Results: One of the radioimmunoassays detected thyroid peroxidase antibodies not only in all children with autoimmune thyroid disorders and children and young adults with type 1 diabetes and thyroid microsomal antibodies, but also in $20 \%$ of healthy control children without microsomal antibodies. With this thyroid peroxidase assay and with microsomal agglutination, $94 \%$ of the children with autoimmune thyroiditis, $71 \%$ of those with Graves' disease, and over $90 \%$ of those with type 1 diabetes and thyroid dysfunction tested positive. In the other radioimmunoassay for thyroid peroxidase antibodies thyroid peroxidase antibody titres in half or more of the children with microsomal antibodies failed to reach the level of positivity given by the produceirs. Eighty five per cent of children with Graves' disease and $71 \%$ of those with autoimmune thyroiditis had thyrotropin receptor antibodies but so did $35 \%$ of children studied for other endocrinological disorders such as delayed growth or puberty.

Conclusions: Testing patients with well characterised disorders of thyroid function and with other endocrine disorders is important in evaluating the efficacy of new diagnostic tests for thyroid autoantibodies.

Thyroid autoantibodies, markers for autoimmune thyroid disorders, are of many specificities. They are found not only in the serum samples of patients with autoimmune thyroiditis but also in some patients with no clinical or biochemical signs of thyroid dysfunction. ${ }^{1-3}$ Thyroid microsomal antibodies tend to correlate better with thyroid disorders than do thyroglobulin antibodies..$^{1-3}$ The test commonly used in assaying thyroid micro- somal antibodies is agglutination of particles coated with human thyroid microsomes. Most of the thyroid microsomal antibodies are directed against the enzyme thyroid peroxidase, thought to be the major antigen of thyroid microsomes. ${ }^{45}$ The prevalence of thyroid peroxidase antibodies has been studied, and thyroid peroxidase has been shown to contain many antigenic determinants..$^{6-9}$ Commercial radioimmunoassays for assaying anti-thyroid peroxidase are now available and their performance has been tested in adults, ${ }^{10-12}$ but not in children. We tested serum samples from children with autoimmune thyroid disease and type 1 diabetes using thyroid microsomal agglutination and two different thyroid peroxidase antibody radioimmunoassays. Sera from other children treated at the Clinics for Endocrinological Disorders and healthy controls were also tested. Thyroglobulin and thyrotropin receptor antibodies, as well as thyroid function, were also determined.

\section{Methods}

The patients comprised children with autoimmune thyroid disorders (autoimmune thyroiditis or Graves' disease), children treated at the Clinics for Endocrinological Disorders, and children with insulin dependent diabetes mellitus (IDDM) of recent onset (table 1). Young adolescents with IDDM of about 12 years' duration with or without thyroid dysfunction were also studied. As controls, children admitted to hospital because of minor surgical operations or psychosomatic disorders were also tested. Tests on thyroid function were performed in all but the controls. Informed consent was obtained from the patients or the parents, and the study was approved by the ethical committee at Aurora Hospital.

\section{TESTS ON THYROID FUNCTION}

Serum concentrations of thyrotropin and $\mathrm{T}_{4}$ were determined by radioimmunoassay (TSHriagnost-hTSH, Behringwerke Inc., Marburg, Germany; $T_{4}$-RIA Becton-Dickinson Inc., Orangeburg, New York) and that of free $T_{4}$ $\left(\mathrm{fT}_{4}\right)$ as previously described. ${ }^{1314}$ The normal values were: $T_{4}$, patients younger than 12 years 65-175 nmol/1, older than 12 years, 65$160 \mathrm{nmol} / \mathrm{l} ; \mathrm{fT}_{4}, 10-25 \mu \mathrm{mol} / \mathrm{l}$; thyrotropin, younger than 12 years, $0.5-6 \mathrm{mU} / 1$ and older than 12 years, $0.2-4.0 \mathrm{mU} / 1$. The size of thyroid glands was estimated by palpation or by ultrasonography. 
Table 1 Disease profiles of patients studied

\begin{tabular}{|c|c|c|c|}
\hline Patients & $n$ & $\begin{array}{l}\text { Mean age, } \\
\text { years (range) }\end{array}$ & $\begin{array}{l}\text { Sex, } \\
F / M\end{array}$ \\
\hline $\begin{array}{l}\text { Autoimmune thyroiditis } \\
\text { Graves' disease`} \\
\text { IDDM-A } \dagger \\
\text { IDDM-B } \\
\text { IDDM-C } \\
\text { Endocrine disorders } \ddagger \\
\text { Controls }\end{array}$ & $\begin{array}{r}18 \\
7 \\
15 \\
11 \\
15 \\
21 \\
20\end{array}$ & $\begin{array}{c}13 \cdot 4(7 \cdot 1-16 \cdot 6) \\
13 \cdot 8(10 \cdot 4-18 \cdot 3) \\
11 \cdot 3(3 \cdot 9-15 \cdot 2) \\
23 \cdot 8(19 \cdot 2-29 \cdot 1) \\
21 \cdot 3(14 \cdot 7-28 \cdot 4) \\
9 \cdot 4(0 \cdot 5-17 \cdot 4) \\
8 \cdot 5(2 \cdot 1-14 \cdot 8)\end{array}$ & $\begin{array}{l}16 / 2 \\
5 / 2 \\
9 / 6 \\
8 / 3 \\
9 / 9 \\
11 / 10 \\
12 / 8\end{array}$ \\
\hline
\end{tabular}

†Type 1 diabetics; tested within two weeks of diagnosis (A) or about 12 years after diagnosis (B and $C$ ); B with thyroid dysfunction; $C$ with normal thyroid function.

tDiagnoses comprised: constitutional delay of growth and puberty $(n=7)$; congenital hypothyroidism $(n=2)$; toxic multinodular goitre $(n=1)$; hypoparathyroidism $(\mathbf{n}=1)$; growth hormone neurosecretory dysfunction $(n=2)$; pubertes praecox (one because of supracellular tumours, one idiopathic); constitutional tall stature $(n=1)$; hypogonadotrophic hypogonadism $(n=1)$; anorchism $(n=1)$; Turner's syndrome $(n=1)$, adrenarche praecox $(n=1)$; nanism due to fetal alcohol syndrome $(n=1)$.
$15 \mathrm{U} / \mathrm{l}$ considered to be in the "grey-area" of the test.

The Statview program was used to calculate the Spearman correlation coefficients.

\section{Results}

Using agglutination, thyroid microsomal antibodies in titres of $\geqslant 400$ were present in $94 \%$ of children with autoimmune thyroiditis (table 2), in $71 \%$ of children with Graves' disease, and in $91 \%$ of type 1 diabetic young adults treated for thyroid dysfunction (IDDMB). The prevalence of microsomal antibodies in children with newly diagnosed IDDM (IDDM-A) and young adults with IDDM but without thyroid dysfunction (IDDM-C) was $20 \%$ and $13 \%$, respectively. None of the control children had thyroid antibodies with this test, while one of the children with an endocrinological disorder, Turner's syndrome, did with a titre of $1 / 400$. High titres of microsomal antibodies were only seen in patients with autoimmune thyroiditis or with IDDM accompanied by thyroid dysfunction: $28 \%$ and $27 \%$, respectively, of these patients had microsomal antibodies in titres of $\geqslant 6400$, and $11 \%$ compared with $18 \%$ in titres of $\geqslant 25000$.

In the thyroid peroxidase test A (TPO-A) $94 \%$ of the children with autoimmune thyroiditis, $71 \%$ of those with Graves' disease, $20 \%$ of children with newly diagnosed type 1 diabetes, all young adults with IDDM and concomitant thyroid disorders, and one of those with an endocrinological disorder (Turner's syndrome) had thyroid peroxidase antibodies in concentrations of $\geqslant 100 \mathrm{U} / \mathrm{ml}$ (suggested limit for positivity) but so did $20 \%$ $(4 / 20)$ of normal controls and $50 \%$ of patients with longstanding IDDM but without thyroid problems (table 3). Concentrations of $\geqslant 1000 \mathrm{U} / \mathrm{ml}$ were found in $61 \%$ of children with autoimmune thyroiditis, in $14 \%$ of the children with Graves' disease, in $71 \%$ of adolescents with IDDM and thyroid dysfunction, and up to $25 \%$ of other diabetics. The proportions of patients with autoimmune thyroiditis or IDDM together with thyroid dysfunction having $\geqslant 10000 \mathrm{U} / \mathrm{ml}$ of thyroid peroxidase antibodies were $17 \%$ and $29 \%$, respectively. The correlation between microsomal antibody titre and the thyroid peroxidase antibody units given by TPO-A test was $0 \cdot 874$.

In the thyroid peroxidase test B (TPO-B) $50 \%$ of the children with autoimmune thyroiditis had antibodies of $\geqslant 10 \mathrm{U} / \mathrm{ml}$ (suggested limit for positivity) as did $29 \%$ of the sidered positive, and those of $\geqslant 10$ but less than

Table 2 Presence of thyroid microsomal antibodies detected by agglutination

\begin{tabular}{|c|c|c|c|c|c|c|}
\hline \multirow[b]{2}{*}{ Patients } & \multicolumn{6}{|c|}{ Number (\%) with antibody titres of } \\
\hline & $<100$ & $\geqslant 100$ & $\geqslant 400$ & $\geqslant 1600$ & $\geqslant 6400$ & $\leqslant 25000$ \\
\hline $\begin{array}{l}\text { Autoimmune thyroiditis } \\
\text { Graves' disease } \\
\text { IDDM-A } \\
\text { IDDM-B } \\
\text { IDDM-C } \\
\text { Endocrinological disorders } \\
\text { Controls }\end{array}$ & $\begin{array}{l}1 / 18(6)^{\star} \\
2 / 7(29) \\
12 / 15(80) \\
0 / 11(0) \\
12 / 15(80) \\
20 / 21(95) \\
20 / 20(100)\end{array}$ & $\begin{array}{l}17 / 18(94) \\
5 / 7(71) \\
3 / 15(20) \\
11 / 11(100) \\
3 / 15(20) \\
1 / 21(5) \\
0 / 20(0)\end{array}$ & $\begin{array}{l}17 / 18(94) \\
5 / 7(71) \\
3 / 15(20) \\
10 / 11(91) \\
2 / 15(13) \\
1 / 21(5) \\
0 / 20(0)\end{array}$ & $\begin{array}{l}12 / 18(67) \\
3 / 7(43) \\
2 / 15(13) \\
8 / 11(73) \\
1 / 15(7) \\
0 / 21(0) \\
0 / 20(0)\end{array}$ & $\begin{array}{l}5 / 18(28) \\
0 / 7(0) \\
0 / 15(0) \\
3 / 11(27) \\
0 / 15(0) \\
0 / 21(0) \\
0 / 20(0)\end{array}$ & $\begin{array}{l}2 / 18(11) \\
0 / 7(0) \\
0 / 15(0) \\
2 / 11(18) \\
0 / 15(0) \\
0 / 21(0) \\
0 / 20(0)\end{array}$ \\
\hline
\end{tabular}

$\star$ Number $(\%)$ with antibodies at the dilution given. 
Table 3 Thyroid peroxidase antibodies detected by TPO-A test (U/ml)

\begin{tabular}{lcllll}
\hline Patients & $<100$ & $\geqslant 100$ & $\geqslant 200$ & $\geqslant 1000$ & $\geqslant 10000$ \\
\hline Autoimmune thyroiditis & $1 / 18(6)$ & $17 / 18(94)$ & $16 / 18(89)$ & $11 / 18(61)$ & $3 / 18(17)$ \\
Graves' disease & $2 / 7(29)$ & $5 / 7(71)$ & $4 / 7(57)$ & $1 / 7(14)$ & $0 / 7(0)$ \\
IDDM-A & $12 / 15(20)$ & $3 / 15(20)$ & $3 / 15(20)$ & $2 / 15(13)$ & $0 / 7(0)$ \\
IDDM-B & $0 / 7(0)$ & $7 / 7(100)$ & $6 / 7(86)$ & $5 / 7(71)$ & $2 / 7(29)$ \\
IDDM-C & $8 / 16(50)$ & $8 / 16(50)$ & $5 / 16(31)$ & $4 / 16(25)$ & $1 / 16(6)$ \\
Endocrinological disorders & $20 / 21(95)$ & $1 / 21(5)$ & $0 / 21(0)$ & $0 / 21(0)$ & $0 / 21(0)$ \\
Controls & $16 / 20(80)$ & $4 / 20(20)$ & $0 / 20(0)$ & $0 / 20(0)$ & $0 / 20(0)$ \\
\hline
\end{tabular}

Table 4 Thyroid peroxidase antibodies detected by TPO-B test (U/ml)

\begin{tabular}{lclll}
\hline Patients & $<2 \cdot 5$ & $\geqslant 2 \cdot 5$ & $\geqslant 100$ & $\geqslant \neq 20$ \\
\hline Autoimmune thyroiditis & $2 / 18(11)$ & $16 / 18(89)$ & $9 / 18(50)$ & $4 / 18(22)$ \\
Graves' disease & $3 / 7(43)$ & $4 / 7(57)$ & $2 / 7(29)$ & $0 / 7(0)$ \\
IDDM-A & $12 / 15(80)$ & $3 / 15(20)$ & $2 / 15(13)$ & $0 / 15(0)$ \\
IDDM-B & $1 / 7(14)$ & $6 / 7(86)$ & $4 / 7(57)$ & $2 / 7(29)$ \\
IDDM-C & $11 / 16(69)$ & $5 / 16(31)$ & $2 / 16(13)$ & $1 / 16(6)$ \\
Endocrinological disorders & $21 / 21(100)$ & $0 / 21(0)$ & $0 / 21(0)$ & $0 / 21(0)$ \\
Controls & $20 / 20(100)$ & $0 / 20(0)$ & $0 / 20(0)$ & $0 / 20(0)$ \\
\hline
\end{tabular}

Table 5 Thyrotropin receptor antibodies ( $/ \mathrm{ml}$ )

\begin{tabular}{lccc}
\hline Patients & $<10$ & $\geqslant 10$ & $\geqslant 15$ \\
\hline Autoimmune thyroiditis & $1 / 14(7)$ & $13 / 14(93)$ & $10 / 14(71)$ \\
Graves' disease & $0 / 7(0)$ & $7 / 7(100)$ & $6 / 7(85)$ \\
IDDM-A & $15 / 15(100)$ & 0 & 0 \\
IDDM-B & $7 / 7(100)$ & 0 & 0 \\
IDDM-C & $9 / 9(100)$ & 0 & 0 \\
Endocrinological disorders & $5 / 20(25)$ & $15 / 20(75)$ & $7 / 20(35)$ \\
Controls & $20 / 20(100)$ & 0 & 0 \\
\hline
\end{tabular}

children with Graves' disease, and $57 \%$ of young adults with IDDM and thyroid disease (IDDM-B), and $13 \%$ of the other type 1 diabetics, while none of the others had $\geqslant 10 \mathrm{U} /$ $\mathrm{ml}$ of thyroid peroxidase antibodies (table 4). The correlation between titres of microsomal antibodies and Units $/ \mathrm{ml}$ in the TPO-B test was 0.867 and that between the units given by TPO-A and -B, 0.892.

Thyroglobulin antibodies were detected in seven patients: three children with Graves' disease $(43 \%)$, two with autoimmune thyroiditis $(11 \%)$, one with Turner's syndrome and in one young adult with longstanding IDDM. All of them also had microsomal antibodies and thyroid peroxidase antibodies in the TPO-A test, but the TPO-B test failed to detect antibodies in two.

Thyrotropin receptor antibodies were detected in $71 \%$ of the children with autoimmune thyroiditis, in $85 \%$ of children with Graves' disease, and in $35 \%$ of children with other endocrinological disorders in concentrations of $\geqslant 15 \mathrm{U} / 1$, and in $93 \%, 100 \%$, and $75 \%$, respectively, in concentrations of $\geqslant 10 \mathrm{U} / 1$ (table 5).

Three of the 18 children with autoimmune thyroiditis were hypothyroid and receiving thyroxine; all the children with Graves' disease were receiving carbimazole and euthyroid, and the young adults with IDDM and thyroid dysfunction as well as the two children with congenital hypothyroidism were also receiving thyroxin and euthyroid. The rest had normal concentrations of thyrotropin and $\mathrm{T}_{4}$ and were clinically euthyroid. The titres of the antibodies tested showed no correlation with the concentrations of TSH or $\mathrm{T}_{4}$.

\section{Discussion}

The autoimmune aetiology of biochemically and clinically diagnosed thyroid dysfunction is usually confirmed by the finding of thyroid autoantibodies. If thyroid antibodies cannot be detected the diagnosis of autoimmune thyroiditis can be confirmed by fine needle aspiration biopsy, a procedure usually required in less than one tenth of the patients. ${ }^{31314}$

The tests for thyroid autoantibodies currently available are assays of thyroid microsomal, thyroid peroxidase, thyroglobulin, and thyrotropin receptor antibodies. In the patients described here thyroglobulin antibodies were rarely detected and only with microsomal antibodies. The prevalence of thyroglobulin antibodies in different patient groups was also similar to that previously reported. ${ }^{31314}$

A comparison of the two thyroid peroxidase tests and the agglutination test routinely used to detect thyroid microsomal antibodies (table 6) showed that if the levels of positivity of the thyroid peroxidase tests given by the manufacturers - that is, 100 and $10 \mathrm{U} / \mathrm{ml}$ were used, one (TPO-A) would detect antibodies in patients with thyroid dysfunction and those with IDDM as often as the agglutination test, but $20 \%$ of the controls would also be positive; the other (TPO-B) would detect about half of the patients with microsomal antibodies by agglutination. If the levels of positivity were adjusted to $\geqslant 200 \mathrm{U} / \mathrm{ml}$ in the TPO-A and to $\geqslant 2.5 \mathrm{U} / \mathrm{ml}$ in the TPO-B test the number testing positive in the three tests would be similar. Up to $98 \%$ of adults with autoimmune thyroid disorders, and up to $20 \%$ of normal adults have been shown to have anti-TPO antibodies by the TPO-A test. ${ }^{10-12}$ The TPO-A test has not been used to detect microsomal (TPO) antibodies in children but in a commercially available enzyme linked immunosorbent assay for thyroid peroxidase $8 \%$ of newly diagnosed children with IDDM and $2 \%$ of the control children had thyroid peroxidase antibodies. ${ }^{15}$

High titres of thyroid peroxidase antibodies $(\geqslant 1000 \mathrm{U} / \mathrm{ml}$ ) by the TPO-A test were found more frequently in IDDM and in thyroid dysfunction than high titres of microsomal antibodies $(\geqslant 6400)$. Whether thyroid peroxidase antibodies would be more sensitive in predicting the development of thyroid dysfunction remains to be established. The reason for the different sensitivities of the TPO-A and -B tests could be that different epitopes were

Table 6 Comparison of agglutination, TPO-A, and TPO-B tests

\begin{tabular}{|c|c|c|c|c|c|}
\hline \multirow[b]{2}{*}{ Test } & \multicolumn{5}{|l|}{ Percentage positive } \\
\hline & $\begin{array}{l}\text { Autoimmune } \\
\text { thyroid disorders }\end{array}$ & $\begin{array}{l}\text { Graves' } \\
\text { disease }\end{array}$ & $I D D M$ & $\begin{array}{l}\text { Endocrinological } \\
\text { disorders }\end{array}$ & Controls \\
\hline $\begin{array}{l}\text { Agglutination titre of } \geqslant 400 \\
\text { TPO-A of } \geqslant 200 / \geqslant 100^{\star} \text { IU } \\
\text { TPO-B of } \geqslant 2 \cdot 5 / \geqslant 10^{\star} \text { IU }\end{array}$ & $\begin{array}{l}94 \\
89 / 94 \\
89 / 50\end{array}$ & $\begin{array}{l}71 \\
57 / 71 \\
57 / 29\end{array}$ & $\begin{array}{l}37 \\
36 / 46 \dagger \\
37 / 21 \ddagger\end{array}$ & $\begin{array}{l}5 \\
0 / 5 \\
0 / 0\end{array}$ & $\begin{array}{l}0 \\
0 / 20 \\
0 / 0\end{array}$ \\
\hline
\end{tabular}

^Positivity levels suggested by the manufacturers.

†14/39(18/39); $¥ 14 / 38(8 / 38)$. 
exposed on thyroid peroxidase preparations used in the tests, a fact which may affect the reactivity and perhaps define different subgroups of patients. ${ }^{16-18}$

The proportion of children with autoimmune thyroiditis and Graves' disease with thyrotropin receptor antibodies in titres of $\geqslant 15 \mathrm{U} / 1$ was $71 \%$ and $85 \%$, respectively. Up to $98 \%$ of adults with Graves' disease and less than $10 \%$ of adults with autoimmune thyroiditis have been shown to have thyrotropin receptor antibodies by the test used here. ${ }^{31920}$ Results using this test have not been reported in children before but other tests have detected these antibodies in up to $98 \%$ of children with Graves' disease and, depending on the assay, in none or up to $70 \%$ of children with autoimmune thyroiditis. ${ }^{21-24}$

None of the patients with type 1 diabetes, whether with thyroid dysfunction or with microsomal/thyroid peroxidase antibodies, had thyrotropin receptor antibodies. The outcome of the autoimmune thyroiditis in children with diabetes differs from that of autoimmune thyroiditis in children without diabetes. Two thirds of the children with diabetes and thyroiditis become hypothyroid as opposed to one third of the children with thyroiditis alone. ${ }^{13} 14$ This suggests that the mechanism(s) involved in the development of thyroid dysfunction in children with type 1 diabetes may differ from those in children with autoimmune thyroiditis.

One third $(n=7)$ of the control children tested positive in the anti-thyrotropin receptor assay at the level of $\geqslant 15 \mathrm{U} / 1$, and $75 \%$ at the level of $\geqslant 10 \mathrm{U} / 1$. We do not know the reason why. The reactivity may have been due to non-specific binding, ${ }^{2526}$ or perhaps due to antibodies against other hormones sharing the alpha chain of thyrotropin. Three of these children were or had been receiving testosterone, two growth hormone and two thyroxine. Further studies are required to resolve the specificity of this reactivity.

Analysis of thyroid autoantibodies in patients with well characterised disorders of thyroid function and with other endocrine disorders is useful in establishing the value of tests for organ specific circulating antibodies. Whether more sensitive and specific methodsfor instance, using cloned peptide fragments of autoantigens ${ }^{27} 28$-might be useful in predicting the development of disorders of thyroid function or in differentiating between different clinical forms of thyroid dysfunction remains to be established. The reason(s) for reactivity in the thyrotropin receptor assay used here need to be studied in detail.

We thank Pirjo Voivola, RN, for help with the patients and Leena Saraste for her patience in preparing the manuscript. The financial support by The Sigrid Juselius Foundation (to SK) and by the Finnish Diabetes Research Foundation (to AM) is gratefully acknowledged.

1 Strakosch CR, Wenzel BE, Row VV, Volpé R. Immunology of autoimmune thyroid diseases. $N$ Engl J Med 1982; 307:1499-507.

2 Baker BA, Charib H, Markowitz H. Correlation of thyroid antibodies and cytological features in suspected autoimmune thyroid disease. Am J Med 1983;74:941-4.

3 Doullay F, Ruf J, Carayon P, Codaccioni JL. Autoantibodies to thyroperoxidase in various thyroid and autoimmune diseases. In: Carayon P, Ruf J, eds. Thyroperoxidase and thyroid autoimmunity. Paris: Colloques Inserm, John Libbey Eurotext Ltd, 1990:285-94.

4 Czarnocka B, Ruf J, Ferrand M, Carayon P, Lissitzky S.
Purification of the human thyroid peroxidase and its identification as the microsomal antigen involved in autoimmune thyroid diseases. FEBS Lett 1985;190: 147-52.

5 Portmann L, Hamada N, Heinrich G, DeGroot LJ. Antithyroid peroxidase antibody in patients with autoimmune thyroid disease: possible identity with anti-microsomal thyroid disease: possible identity with anti-microson

6 Doble ND, Banga JP, Pope R, Lalor E, Kulduff P McGregor AM. Autoantibodies to the thyroid microsomal/thyroid peroxidase antigen are polyclonal and directed to several distinct antigenic sites. Immunology 1988;64:23-9.

7 Kohno Y, Naito N, Hiyama Y, et al. Thyroglobulin and thyroid peroxidase share common epitopes recognized by autoantibodies from patients with chronic autoimmune
thyroiditis. J Clin Endocrinol Metab 1988;67:899-907.

8 Banga JP, Tomlinson RWS, Doble N, Odell E, McGregor AM. Thyroid microsomal/thyroid peroxidase autoantibodies show discrete patterns of cross-reactivity to myeloperoxidase, lactoperoxidase and

9 Mariotti S, Caturegli P, Piccolo P, Barbesino G, Pinchera A Antithyroid peroxidase autoantibodies in thyroid diseases. J Clin Endocrinol Metab 1990;71:661-9.

10 Bogner U, Kotulla P, Peters H, Schleusener H. Thyroid peroxidase/microsomal antibodies are not identical with thyroid cytotoxic antibodies in autoimmune thyroiditis. Acta Endocrinol 1990;123:431-7.

11 Bornet H, Madec AM, Rodien P, et al. Evaluation of antiTPO antibody determination in various clinical situations. In: Carayon P, Ruf J, eds. Thyroperoxidase and thyroid autoimmunity. Paris: Colloques Inserm, Vol 207, John Libbey Eurotext Ltd, 1990:315-20.

12 Feldt-Rasmussen U, Hoier-Madsen $M$, Bech $K$, et al. AntiTPO antibodies in non-thyroid autoimmune diseases. In Carayon P, Ruf J, eds. Thyroperoxidase and thyroid autoimmunity. Paris: Colloques Inserm, Vol 207, John Libbey Eurotext Ltd, 1990:297-301.

13 Mäenpää J, Lautenschlager I, Nyberg M, Koskimies S Kontiainen S. Thyroid-infiltrating lymphocytes, thyroid function, and HLA-DR in juvenile autoimmune thyroiditis. Acta Endocrinol 1989;121:573-7.

14 Kontiainen S, Schlenzka A, Koskimies S, Rilva A, Mäenpää $J$. Autoantibodies and autoimmune diseases in young diabetics. Diabetes Res 1990;13:151-6.

15 Landin-Olsson M, Karlsson A, Dahlquist G, et al. Islet cel and other organ-specific autoantibodies in all children developing type 1 (insulin-dependent) diabetes mellitus in Sweden during one year and in matched control children. Diabetologia 1989;32:387-95.

16 Hamada N, Jaeduck N, Portman L, Ito K, DeGroot LJ Antibodies against denatured and reduced thyroid microsomal antigen in autoimmune thyroid disease. J Clin Endocrinol Metab 1987;64:230-8.

17 Naito N, Saito K, Hosoya T, et al. Antithyroglobulin autoantibodies in sera from patients with chronic thyroiditis and from healthy subjects: differences in cross-reactivity with thyroid peroxidase. Clin Exp Immunol 1990;80:4-10.

18 Kohno Y, Naito N, Yamaguchi F, Saito K, Niimi H, Hosoya T. Autoantibodies inhibiting thyroid peroxidase enzyme activity: specificities of anti-thyroid peroxidase antibodies in healthy subjects and patients with systemic lupus erythematosus. In: Carayon P, Ruf J, eds. Thyroperoxidase and thyroid autoimmunity. Paris: Colloques Inserm idase and thyroid autoimmunity. Paris: Colloques 1

19 Rootwelt K. Evaluation of a radioreceptor assay for TSH receptor autoantibodies. Scand J Clin Lab Invest 1988 48:157-64.

20 Schifferdecker E, Schulz F, Schöffling K. Die Bestimmung von TSH-Rezeptor-Antikörpern-Klinische Wertigkeit. Klin Wochenschr 1986;64:8-14.

21 Brown RS, Kertiles LP, Rosenfield C, Kleinmann RE Crigler JF. Thyrotropin-receptor autoantibodies in children and young adults with Graves' disease. $A m J$ Dis Child 1986;140:238-41.

22 Matsuura N, Konishi J, Yuri K, et al. Comparison of atrophic and goitrous auto-immune thyroiditis in children: clinical, laboratory and TSH-receptor antibody dren: clinical, laboratory and TSH-rece

23 Foley TP Jr, White C, New A. Juvenile Graves' disease: usefulness and limitations of thyrotropin receptor antibody determinations. J Pediatr 1987;110:378-86.

24 Lu C, Kasagi K, Hidaka A, Hatabu H, Iida Y, Konishi H Simultaneous measurement of TSH-binding inhibito immunoglobulin and thyroid stimulating autoantibody activities using cultured FRTL-5 cells in patients with untreated Graves' disease. Acta Endocrinol 1990;123: untreated

25 De Bruin TWA, Braverman LE, Brown RS. Heterogeneity of TSH receptor-binding antibodies in Hashimoto's thyroiditis and Graves' disease. Am J Med Sci 1990; 299:291-7.

26 Hashim FA, Creagh FM, El Hawrani A, Parkes AB Buckland PR, Rees Smith B. Characterization of TSH antagonist activity in the serum of patients with thyroid disease. Clin Endocrinol 1986;25:275-81.

27 Ludgate M, Mariotti S, Libert F, et al. Antibodies to human thyroid peroxidase in autoimmune thyroid disease: studies with a cloned recombinant complementary deoxyribonucleic acid epitope. J Clin Endocrinol Metab 1989, 68:1091-6.

28 Yokoyama N, Taurog A, Klee GG. Thyroid peroxidase and thyroid microsomal autoantibodies. J Clin Endocrinol Metab 1989;68:766-73. 